\title{
Is Solar Rooftop Power Still Attractive Amid Decreasing Fuel Prices? The Case of Indonesian Electrical Power
}

\author{
Dodik Siswantoro*‡(D), Sari Lestari Zainal Ridho**(iD) \\ * Department of Accounting Universitas Indonesia Depok, Indonesia \\ ** Sari Lestari Zainal Ridho, Politeknik Negeri Sriwijaya \\ (dodik.siswantoro@ui.ac.id, sarilestari@polsri.ac.id) \\ ¥Corresponding Author; Dodik Siswantoro, Department of Accounting Universitas Indonesia Depok, Indonesia, \\ Tel: +62 21 7863558, Fax: +62 21 7863558, dodik.siswantoro@ui.ac.id
}

Received: 04.05.2021 Accepted:13.06.2021

\begin{abstract}
The socialization of solar rooftop panel power in Indonesia has been massive since 2019; however, since 91.87\% of the country's electrical power comes from fuel, a massive amount of support is required to shift to renewable electricity sources. Ministry regulation No. 49/2018 on solar rooftop panel power has provided an export mechanism. However, many people have commented that this regulation does not entice consumers to use solar rooftop panels; in practice, it may not be applicable. In addition, the sharp decrease in fuel prices in 2020 may lead people to choose not to use grid solar panels. The objective of this paper was to analyze the impact of decreasing fuel prices on the attractiveness of solar rooftop power. Data was collected on Indonesian electricity and fuel prices, correlated, and analyzed based on the trade-off of using a grid solar panel. On-grid solar panels need substantial early capital investment and a low electricity selling price (only 0.65 from the normal rate). Without an export import meter, this would not be effective as an oversupply of electricity from home would be a burden as it is not counted as an electricity export. Decreasing fuel prices for power plants makes grid solar panels unattractive, as the opportunity cost is small. Furthermore, the government still uses different prices (the contracted price, which is relatively stagnant), which may not refer to the actual price.
\end{abstract}

Keywords grid, solar panel, fossil fuel, price, electricity price

\section{Introduction}

The success of renewable energy (RE) power depends on the level of governmental support. For example, the shift from polluted to zero-emission power plants requires support from the government and proactive action from the public. Almost $100 \%$ of the power in Iceland, Paraguay, Norway, and Costa Rica is based on RE, including hydro, solar, wind, and geothermal sources (World Economic Forum video). Meanwhile, the United Kingdom has been decreasing its dependence on coal since 1998 and its dependence on oil since 1981 (www.electricinsights.co.uk).

The development of RE for electricity does not depend on a country's overall development status. Based on World Bank data, of the 11 countries with nearly $100 \%$ reliance on RE in 2015, only two were developed countries: Iceland and
Norway; the others were countries with the lowest income per capita, including Zambia, Ethiopia, Tajikistan, and Congo.

In 2017 , the biggest producers of solar panel power were China (130.4GW) and the United States (85.3GW) [1]. China's production rose from $6 \mathrm{GW}$ in 2011 to $170 \mathrm{GW}$ in 2018 [2], and its targets are $370 \mathrm{GW}$ in 2024 and $1300 \mathrm{GW}$ in 2050 [3]. Similarly, Vietnam aims be the largest solar power producer in South East Asia $(5.5 \mathrm{GW})$ and obtain half of its electricity from RE sources by 2035. Canada has also been replacing coal power with solar power since 2019 (World Economic Forum). With significant governmental support, the price of electricity from solar panels can be much cheaper than from coal. This can be an incentive for people to install solar energy.

In Indonesia, there is a research gap related to the attractiveness of solar rooftop power amid decreasing fuel 
(oil, coal, and gas) prices. No relevant studies have discussed the feasibility and characteristics of solar panels or on-grid solar rooftop power, especially in the context of decreasing fuel prices.

Therefore, the present study aimed to analyze the impact of decreasing fuel prices on the attractiveness of on-grid solar rooftop power despite the high costs of new power plant installations. The paper starts with an introduction on the background of solar panel power. The literature review explains the importance of solar panel power and on-grid issues. The research method section describes how the study was conducted, and the analysis section discusses how ongrid solar rooftop power practices and attractiveness in Indonesia were analyzed. The conclusion section proposes recommendations for achieving on-grid solar rooftop power.

\section{Literature Review}

Solar panel grid use has had an annual performance rate of $79 \%$ and a variation of $58 \%$ to $98 \%$ [4]. It means maximum capacity to create electricity. A similar study found that solar power output is unstable [5]. Another study found that the most efficient solar power model can be calculated based on mathematical simulations [6]. Meanwhile, a mix of battery and solar panel power was found to be the most efficient combination for this scheme [7].

Solar rooftops can minimize electric shortages with governmental support. Without government support, it is difficult to achieve, as has been the case in Nepal [8].

In Turkey, the government offers incentives for a home rooftop program with a grid system. The feasibility is good, the payback period is eight years, the internal rate of return (IRR) is above $13.12 \%$, and the profitability index (PI) is above two, but it varies. The results have not been the same in all provinces, since each province has a different solar radiation level. In addition, the government should give more incentives to this sector, including a grid tariff and a subsidy for initial costs [9]. The higher energy part would decrease the total power tariff of the prosumer, which has been simulated in Norway. Then, the tariff would be similar to the energy tariff [10]. People need certainty regarding the benefits of using solar rooftops, especially on-grid schemes, which can export electricity.

Similarly, in Thailand, despite the highest development of solar power, which is targeted at $6,000 \mathrm{MW}$ in 2035 , the development of solar rooftop power has been slow because the government offered a lower tariff. Furthermore, a feasibility study was not achieved. To attain the minimum IRR $(12 \%)$, the government should (a) increase the tariff to $0.294 \mathrm{USD} / \mathrm{kWh}$ (b) provide a tax subsidy and (c) offer low interest rate financing [11]. However, small incentives would cause households to install solar power for electricity. Similarly, if the initial cost and the interest rate were low, this would be attractive to investors [12].

A bigger solar panel would decrease costs and government policies [13]. In Serbia, a bigger solar panel plant can create a payback period of eight years and an IRR until $14.7 \%$, compared to Montenegro. Stationary battery systems (SBS) in Germany have yielded better profits for investors and higher returns than other systems [14]. There should be an optimum choice to maximize solar rooftop power performance.

\section{Research Method}

In the present study, data on the price of fuel sources, such as oil, coal, and gas, was collected from stlouisfed.org, which provides daily data on oil and gas on a monthly basis. Other data was gathered from the annual report of Pusat Listrik Negara (PLN), Statistik PLN, the National Energy Council, and relevant trusted third-party websites. Data was collected for the period of 2014 to 2018 . Some 2019 and 2020 thirdparty data, such as tariff details, cost of goods sold (COGS), and energy selling prices, was not available.

The data was analyzed based on a specific topic on solar rooftop panel power to relate from beginning sources and mapping to related topics on solar rooftop panel power. Statistical tools, including descriptive and correlation tests, were used. This paper is based on data gathered from some relevant sources.

\section{Analysis}

Among other countries, Indonesia has a competitive electricity price; Singapore had the highest price, followed by the Philippines (see Table 1). Although the electricity price is subsidized, Indonesia has the sixth-largest energy subsidy. The electricity subsidy was USD 7.7 billion in 2010 (Chattopadhyay and Jha, 2014), USD 7.8 billion in 2013 [15], and USD 11.2 billion in 2016 [16]. This caused a national budget burden and other RE to develop as it also needs similar treatment for this sector.

Table 1. Price comparison of power price in ASEAN (in $\mathrm{USD} / \mathrm{KWH}$ ) [17]

\begin{tabular}{|l|r|r|r|r|r|r|}
\hline & INA & MAL & THA & SIN & PHI & VIE \\
\hline Household & 11.00 & 10.00 & 12.41 & 19.97 & 18.67 & 10.59 \\
\hline $\begin{array}{l}\text { Average } \\
\text { Business - } \\
\text { Low }\end{array}$ & 11.00 & 13.58 & 11.00 & 14.30 & 12.23 & 13.44 \\
\hline $\begin{array}{l}\text { Major } \\
\text { Business - } \\
\text { Medium }\end{array}$ & 8.36 & 9.60 & 11.00 & 14.02 & 11.98 & 12.36 \\
\hline $\begin{array}{l}\text { Average } \\
\text { Industry - } \\
\text { Medium }\end{array}$ & 8.36 & 8.29 & 8.36 & 13.05 & 11.69 & 7.81 \\
\hline $\begin{array}{l}\text { Major Industry } \\
\text { - High }\end{array}$ & 7.47 & 7.76 & 8.36 & 12.72 & 11.63 & 7.41 \\
\hline
\end{tabular}

Almost $91.87 \%$ of power in Indonesia is based on nonrenewable energy (RNE), which may lead to problems if RNE becomes unavailable (Statistik PLN 2018). Indonesia has a great deal of coal mining, and $59 \%$ of power plants are based on coal. Coal is the cheapest resource in Indonesia at USD 6 cents per kWh, while LNG or gas power was about USD 10 cents per $\mathrm{kWh}$ in 2019 [18] 


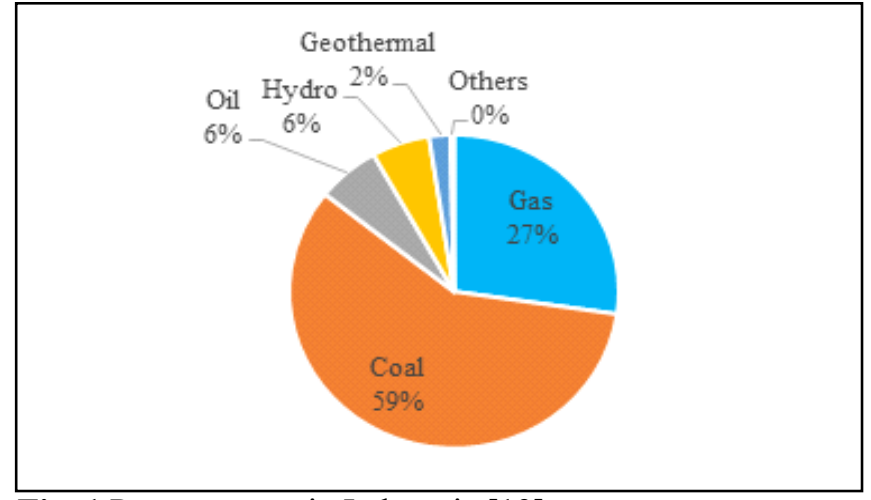

Fig. 1.Power source in Indonesia [19].
In Indonesia, the price of each type of power is determined by a specific regulation. Coal has a ceiling price of USD 70 per metric ton; suppliers cannot sell coal for electricity above that price. However, cost of goods sold (COGS) is only USD 35. The gap between costs and selling prices to power plants is almost $100 \%$, which benefits coal miners. The oil supply price depends on the Indonesia Crude Price (ICP) reference; it was USD 51.19 per barrel in 2017 and around USD 67.47 per barrel in 2018. The gas price increased Rp14,962 per MMBTU; in 2017, it was Rp121,493 [17]. Changes in raw energy prices affect the prices for power plants as well (see Table 2).

Table 2. Price of fuel price for power and market [17-20-21-22-23-24]

\begin{tabular}{|c|c|c|c|c|c|c|}
\hline Year & $\begin{array}{l}\text { Oil (kilo } \\
\text { liter) }\end{array}$ & $\begin{array}{l}\text { Actual Oil } \\
\text { (USD/barrels) }\end{array}$ & Coal (Rp/kg) & $\begin{array}{l}\text { Actual Coal (USD/ } \\
\text { metric ton) }\end{array}$ & $\begin{array}{l}\text { Gas }(\mathrm{Rp} / \\
\text { MMSCF) }\end{array}$ & $\begin{array}{l}\text { Actual Gas (USD/ } \\
\text { Million BTU) }\end{array}$ \\
\hline 2020 & ? & 41 & ? & 71 & ? & 1.8 \\
\hline 2019 & n.a & 57 & n.a & 84.6 & n.a & 2.5 \\
\hline 2018 & $7.421,62$ & 65.2 & 767,08 & 113.2 & $119.115,94$ & 3.1 \\
\hline 2017 & $6,259.85$ & 50.8 & 782.61 & 94.1 & $106,480.22$ & 2.9 \\
\hline 2016 & $4.855,19$ & 43.2 & 611,23 & 70.0 & $101.123,24$ & 2.5 \\
\hline 2015 & $6,395.47$ & 48.6 & 662.46 & 62.6 & $105,917.94$ & 2.6 \\
\hline 2014 & $9.847,04$ & 93.1 & $1.004,50$ & 75.7 & $105.876,17$ & 4.3 \\
\hline
\end{tabular}

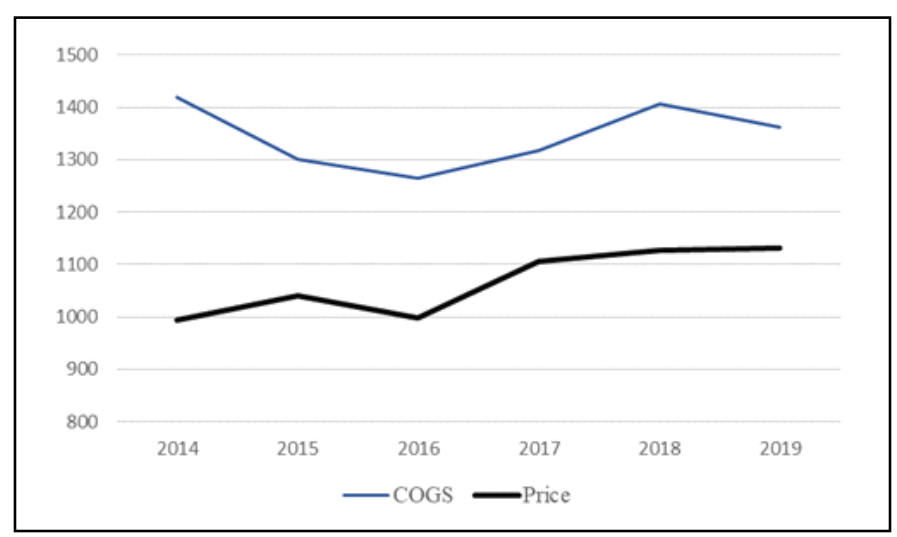

There is a strong relationship between the raw energy source and the price for power plants, especially oil with a correlation of 0.978 , followed by coal with a correlation of 0.21 and gas with a correlation of 0.149 . However, the price of fuel had a strong correlation with COGS of electricity-for example, oil (0.907), coal (0.839), and gas (0.655) — but not for the price after subsidy, except in the case of gas $(0.775)$ (see Table 3). This means that COGS may reflect the true price of each power category. Furthermore, the price of electricity is based on the subsidy for each year.

Fig. 2. Price and cost of electricity [25]

Table 3. Correlation

\begin{tabular}{|l|l|r|r|r|r|r|}
\hline \multicolumn{2}{|c|}{} & Oilcost & Coalcost & Gascost & COGS & Price \\
\hline Oilcost & $\begin{array}{l}\text { Pearson } \\
\text { Correlation }\end{array}$ & 1 & $.943^{*}$ & .314 & $.907^{*}$ & -.111 \\
\cline { 2 - 7 } & Sig. (2-tailed) & & .016 & .607 & .034 & .859 \\
\cline { 2 - 7 } & $\mathrm{N}$ & 5 & 5 & 5 & 5 & 5 \\
\hline Coalcost & $\begin{array}{l}\text { Pearson } \\
\text { Correlation }\end{array}$ & $.943^{*}$ & 1 & .186 & .839 & -.091 \\
\cline { 2 - 7 } & Sig. (2-tailed) & .016 & & .765 & .076 & .884 \\
\cline { 2 - 7 } & $\mathrm{N}$ & 5 & 5 & 5 & 5 & 5 \\
\hline Gascost & $\begin{array}{l}\text { Pearson } \\
\text { Correlation }\end{array}$ & .314 & .186 & 1 & .655 & .775 \\
\cline { 2 - 7 } & Sig. (2-tailed) & .607 & .765 & & .230 & .124 \\
\hline
\end{tabular}




\begin{tabular}{|l|l|r|r|r|r|r|}
\hline & $\mathrm{N}$ & 5 & 5 & 5 & 5 & 5 \\
\hline \multirow{5}{*}{ COGS } & $\begin{array}{l}\text { Pearson } \\
\text { Correlation }\end{array}$ & $.907^{*}$ & .839 & .655 & 1 & .219 \\
\cline { 2 - 7 } & Sig. (2-tailed) & .034 & .076 & .230 & & .723 \\
\cline { 2 - 7 } & $\mathrm{N}$ & 5 & 5 & 5 & 5 & 5 \\
\hline \multirow{3}{*}{ Price } & $\begin{array}{l}\text { Pearson } \\
\text { Correlation }\end{array}$ & -.111 & -.091 & .775 & .219 & 1 \\
& Sig. (2-tailed) & .859 & .884 & .124 & .723 & \\
\cline { 2 - 7 } & $\mathrm{N}$ & 5 & 5 & 5 & 5 & 5 \\
\hline
\end{tabular}

*. Correlation is significant at the 0.05 level (2-tailed).

As shown in Table 2, in 2020, each raw energy source was low; oil was USD 41/barrels, coal was USD 71/metric ton, and gas was USD 1.8 /million BTU). Starting in 2014, this caused the price of each power source to be lower than the previous year, except for coal (the lowest was in 2016). This condition can cause COGS of electricity to be low and minimize the power subsidy. This can also be a challenge for solar rooftop power, as the price of electricity could be lower than in the previous year; if the selling price is also lower than in the previous year, solar rooftop power could become unattractive to people.

The tariff of electricity should be high to compensate electricity producer from the solar panel. Solar panel producer would reduce electricity usage as they also produce electricity. If the supply is more than electricity usage, it will create an electricity export mechanism as explained above. In figure 3 , we could see that if the electricity tariff is high, it will benefit the solar panel producer. Export mechanism would occur from 10AM until 14AM.

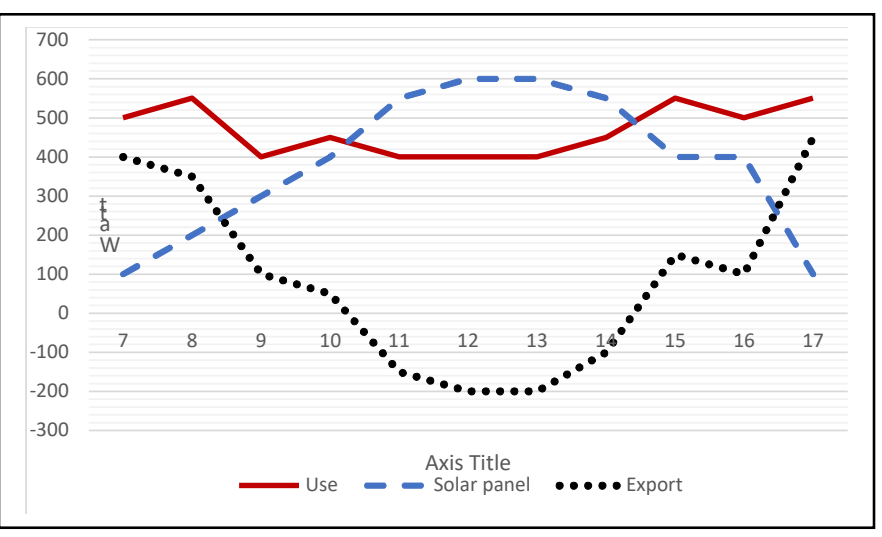

Fig. 2.Illustration of Watt usage and Solar Producer [25]

On-grid solar rooftop power can generate income from electricity exports. For example, a house with 2200 watt can only have $2.2 \mathrm{kWh}$ for solar rooftop power with an on-grid scheme. Four hours of sunlight every day for 30 days would result in $264 \mathrm{kWh}$. That amount is then multiplied by 0.65 as regulated, and the result is $171.6 \mathrm{kWh}$. That amount is multiplied by the price of electricity (Rp1467.28/kWh), and the result is Rp251,785.25. If the initial investment for this on-grid solar rooftop was Rp45 million, the payback period would be a minimum of 15 years (assuming the exclusion of the loan, interest, and maintenance costs and selling price stability). This is not including the electricity subsidy from solar panel as the supply is lower than demand usage. Let's assume it produced two hours below the export mechanism, so the calculation is $2.2 \mathrm{kWh} \quad \mathrm{x} \quad 2 \mathrm{hr} \quad \mathrm{x}$ 30days $\mathrm{x}$ Rp1467.28/kWh, so the result is Rp193,680.96. Then the payback period becomes eight years.

If the raw energy price also decreased significantly, the selling price of electricity could decrease, making this investment unattractive. According to a similar case in Thailand, if feasibility was below people's expectations, few people would invest in on-grid solar rooftop power (Tantisattayakul and Kanchanapiya, 2017). In the global issue, it is called a feed-in tariff (FIT), which should be profitable. The other issue is that the larger the solar rooftop power, the more efficient the solar rooftop; this idea is supported by Kaschub et al. (2016).

\section{Conclusion}

Currently, on-grid solar rooftops are not economically feasible in Indonesia as the selling price is low and the initial investment and maintenance costs are quite high. In addition, decreasing the price of raw fuel resources could decrease the feasibility of on-grid solar rooftops. This is also the case in Thailand, where solar power was well developed, but fuel power subsidies were lower than in Indonesia.

To achieve on-grid solar rooftop power, Indonesia should cross-subsidize fuel power and on-grid solar rooftop power based on the selling price (FIT). People would install on-grid solar rooftop power if feasibility was attractive, the payback period was below seven years, and the IRR was above $11 \%$. On-grid solar rooftop hardware should also be subsidized to encourage people to buy these materials, and maintenance should be subsidized as well.

\section{References}

[1] N. Walker, "Top 10 solar-producing countries," 2017. [Online].

Available: https:/energydigital.com/sustainability/top-10-solarproducing-countries.

[2] F. Hao, "Chinese cities can produce solar power below grid-supplied price, report finds," 2019. [Online]. Available: https://chinadialogue.net/en/energy/11575chinese-cities-can-produce-solar-power-below-gridsupplied-price-report-finds/.

[3] "Top 10 Solar Energy Markets in the World in 2019," 2019. [Online]. Available: https:/www.solarfeeds.com/mag/solar-energy-marketsin-the-world/. 
[4] K. Attari, A. Elyaakoubi, and A. Asselman, "Performance analysis and investigation of a gridconnected photovoltaic installation in Morocco," Energy Reports, vol. 2, pp. 261-266, 2016, doi: 10.1016/j.egyr.2016.10.004.

[5] I. Ibrik, "Power quality and performance of gridconnected solar PV system in Palestine," Int. J. Eng. Res. Technol., vol. 12, no. 9, pp. 1570-1577, 2019.

[6] M. A. Khan and S. Mishra, "Grid Connected Energy Efficient Building with Roof Top SPV," 2017 Recent Dev. Control. Autom. Power Eng., vol. 3, pp. 120-124, 2017.

[7] A. L. Shah and A. T. Al-Awami, "Financial benefits by installing PV generation and energy storage systems for households," 2017 Saudi Arab. Smart Grid Conf. SASG 2017, pp. 1-7, 2018, doi: 10.1109/SASG.2017.8356475.

[8] B. R. Gautam, F. Li, and G. Ru, “Assessment of urban roof top solar photovoltaic potential to solve power shortage problem in Nepal," Energy Build., vol. 86, pp. 735-744, 2015, doi: 10.1016/j.enbuild.2014.10.038.

[9] A. C. Duman and Ö. Güler, "Economic analysis of gridconnected residential rooftop PV systems in Turkey," Renew. Energy, vol. 148, pp. 697-711, 2020, doi: 10.1016/j.renene.2019.10.157.

[10] H. Sæle and B. A. Bremdal, "Economic evaluation of the grid tariff for households with solar power installed," in CIRED - Open Access Proceedings Journal, 2017, pp. 2007-2010, doi: 10.1049/oap-cired.2017.0556.

[11] T. Tantisattayakul and P. Kanchanapiya, "Financial measures for promoting residential rooftop photovoltaics under a feed-in tariff framework in Thailand," Energy Policy, vol. 109, pp. 260-269, 2017, doi: 10.1016/j.enpol.2017.06.061.

[12] A. Zahedi, "How expensive is grid-connected solar photovoltaic in Marrakesh: An economic analysis," in Proceedings of 2015 IEEE International Renewable and Sustainable Energy Conference, IRSEC 2015, 2016, doi: 10.1109/IRSEC.2015.7455032.

[13] R. Torabi, N. Sahovic, S. Rodrigues, H. Mata-Lima, and F. Morgado-Dias, "Cost-effectiveness analysis of roof-Top PV systems in Montenegro and Serbia," in 4th International Symposium on Environment Friendly Energies and Applications, EFEA 2016, 2016, doi: 10.1109/EFEA.2016.7748773.
[14] T. Kaschub, P. Jochem, and W. Fichtner, "Solar energy storage in German households: profitability, load changes and flexibility," Energy Policy, vol. 98, pp. 520532, 2016, doi: 10.1016/j.enpol.2016.09.017.

[15] IER, "Developing Countries Subsidize Fossil Fuel Use, Artificially Lowering Prices," 2014. [Online]. Available:

https://www.instituteforenergyresearch.org/fossilfuels/gas-and-oil/developing-countries-subsidize-fossilfuel-use-artificially-lower-prices-

2/?_cf_chl_captcha_tk_=0eda1115e5963def8d1970015 $23 \overline{3 a d} 3 \overline{9}$ e9e $\overline{5}$ 1 $121-1 \overline{6} 23418167-0$ AWfvBnIZAJOyaGOdEv4axk5XUh7KYsjKMaB.

[16] IER, "Global Fossil Fuel Consumption Subsidies Abound, But Not in the United States," 2018. [Online]. Available:

https://www.instituteforenergyresearch.org/fossilfuels/global-fossil-fuel-consumption-subsidies-aboundnot-united-states/.

[17] PLN, Statistik PLN 2018. 2018.

[18] V. N. Setiawan, “Ada PLTU Mulai Beroperasi, PLN Butuh 109 Juta Ton Batu Bara di 2020,” 2019. [Online]. Available:

https://katadata.co.id/febrinaiskana/berita/5e9a503b70ef7 /ada-pltu-mulai-beroperasi-pln-butuh-109-juta-ton-batubara-di-2020.

[19] N. E. Council, Indonesia Energy Outlook 2019. 2019.

[20] FRED, "No Title." [Online]. Available: https://fred.stlouisfed.org/.

[21] PLN, Statistik PLN 2014. 2014.

[22] PLN, Statistik PLN 2015. 2015.

[23] PLN, Statistik PLN 2016. 2016.

[24] PLN, Statistik PLN 2017. 2017.

[25] N. P. E. Wiratmini, "PLN Tekan Biaya Pembangkitan Listrik," 2019. [Online]. Available: https://ekonomi.bisnis.com/read/20190627/44/938477/pln -tekan-biaya-pembangkitan-listrik. 